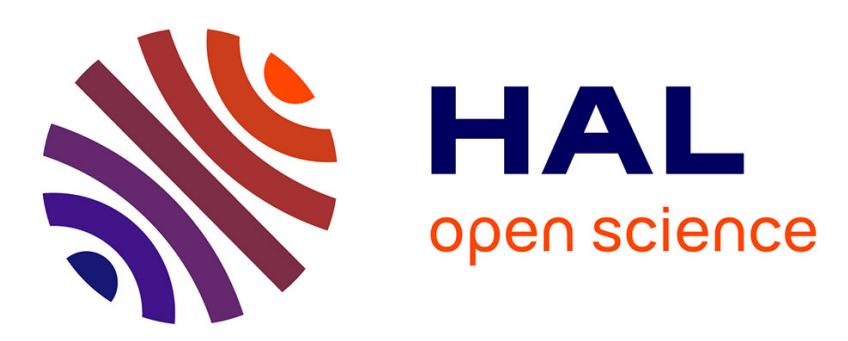

\title{
Laser welding of $\mathrm{Cu}$-Al-Be shape memory alloys: Microstructure and mechanical properties
}

Jp Oliveira, Z. Zeng, Sophie Berveiller, Denis Bouscaud, F.M. Braz

Fernandes, R.M. Miranda, N. Zhou

\section{- To cite this version:}

Jp Oliveira, Z. Zeng, Sophie Berveiller, Denis Bouscaud, F.M. Braz Fernandes, et al.. Laser welding of $\mathrm{Cu}-\mathrm{Al}-\mathrm{Be}$ shape memory alloys: Microstructure and mechanical properties. Materials \& Design, 2018, 148, pp.145-152. 10.1016/j.matdes.2018.03.066 . hal-01827578

\section{HAL Id: hal-01827578 \\ https://hal.science/hal-01827578}

Submitted on 2 Jul 2018

HAL is a multi-disciplinary open access archive for the deposit and dissemination of scientific research documents, whether they are published or not. The documents may come from teaching and research institutions in France or abroad, or from public or private research centers.
L'archive ouverte pluridisciplinaire HAL, est destinée au dépôt et à la diffusion de documents scientifiques de niveau recherche, publiés ou non, émanant des établissements d'enseignement et de recherche français ou étrangers, des laboratoires publics ou privés. 


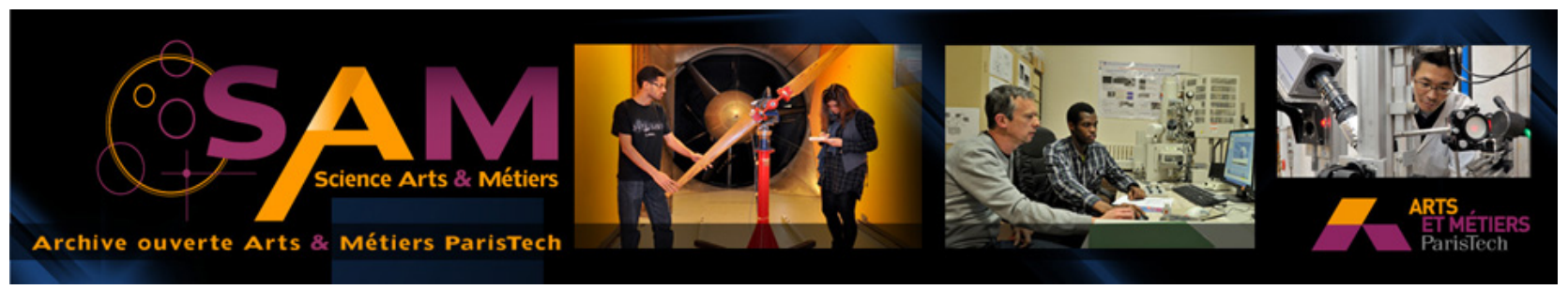

Science Arts \& Métiers (SAM)

is an open access repository that collects the work of Arts et Métiers ParisTech researchers and makes it freely available over the web where possible.

This is an author-deposited version published in: http://sam.ensam.eu

Handle ID: .http://hdl.handle.net/null

\section{To cite this version :}

Sophie BERVEILLER, JP. OLIVEIRA, Z. ZENG, Denis BOUSCAUD, F.M. BRAZ FERANDES, R.M. MIRANDA, N. ZHOU - Laser welding of $\mathrm{Cu}-\mathrm{Al}-\mathrm{Be}$ shape memory alloys: Microstructure and mechanical properties - Materials and Design n¹48, p.145 - 152 - 2018 


\title{
Laser welding of Cu-Al-Be shape memory alloys: Microstructure and mechanical properties
}

\author{
J.P. Oliveira ${ }^{\mathrm{a}, \mathrm{b}, \mathrm{c}, *}$, Z. Zeng $^{\mathrm{d}}$, S. Berveiller ${ }^{\mathrm{e}}$, D. Bouscaud ${ }^{\mathrm{e}}$, F.M. Braz Fernandes ${ }^{\mathrm{a}}$, R.M. Miranda ${ }^{\mathrm{c}}$, N. Zhou $^{\mathrm{b}}$ \\ a CENIMAT/i3N, Faculdade de Ciências e Tecnologia, Universidade Nova de Lisboa, Portugal \\ ${ }^{b}$ Centre for Advanced Materials Joining, University of Waterloo, Canada \\ c UNIDEMI, Faculdade de Ciências e Tecnologia, Universidade Nova de Lisboa, Portugal \\ d School of Mechatronics Engineering, University of Electronic Science and Technology of China, China \\ e Laboratoire d'Etude des Microstructures et de Mécanique des Matériaux LEM3 (UMR CNRS 7239), 4 rue Augustin Fresnel, 57078 Metz, France
}

\section{H I G H L I G H T S}

- Successful laser welding of $\mathrm{Cu}-\mathrm{Al}-\mathrm{Be}$ shape memory alloys

- The joints exhibit excellent superelastic properties.

- Superelasticity is preserved between -40 and $100{ }^{\circ} \mathrm{C}$.

- The joints can be used as energy absorptions devices.

\section{GR A P H I C A L A B S T R A C T}

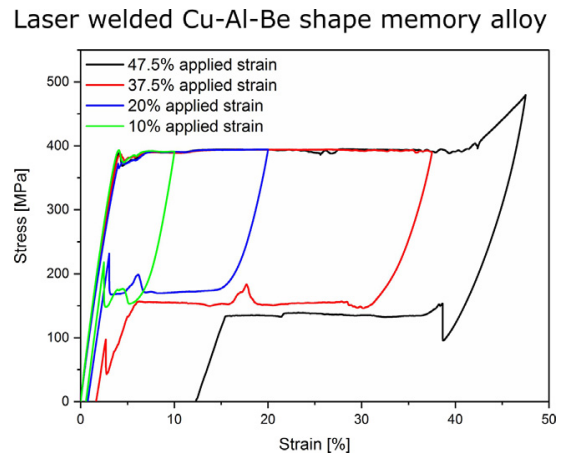

A B S T R A C T

\section{Introduction}

Shape memory alloys have the ability to undergo a reversible thermoelastic phase transformation from the parent phase austenite to a product phase martensite. This particular behaviour is responsible for two main functional properties: superelasticity and shape memory effect [1]. In the former one, the martensitic transformation is induced by applied thermomechanical loading of the austenitic phase, leading to important inelastic strains which are recovered upon unloading due to the reverse phase transformation to austenite. Austenite can transform into martensite during mechanical loading, leading to an inelastic deformation that can be recovered spontaneously upon unloading [2]. 
For the shape memory effect, the material is deformed in the martensitic state, leading to permanent inelastic strains upon unloading. These can be removed by heating up the material to the austenitic phase again: the initial shape is restored triggering the shape memory effect [3].

Cu-based shape memory alloys are considered to be possible substitutes of NiTi, the most used shape memory alloy, owing to their lower production costs and recent improvements on their mechanical properties $[4,5]$. There are different $\mathrm{Cu}$-based systems, with the most important ones being $\mathrm{Cu}-\mathrm{Al}-\mathrm{Mn}$ [6], $\mathrm{Cu}-\mathrm{Al}-\mathrm{Ni}$ [7] and $\mathrm{Cu}-\mathrm{Al}-\mathrm{Be}$ [8]. The latter one presents, aside from the superelastic and shape memory effects, other interesting properties: strong sound, vibration and mechanical damping capability; high mechanical strength; and resistance to corrosion [9]. These alloys exhibit also a particular technological interest for low and intermediate temperature applications [8]: as a result of the introduction of small amounts of $\mathrm{Be}$, the transformation temperatures decrease drastically, allowing for the occurrence of superelasticity at very low temperatures. In fact, some empirical formulae have been proposed to determine the transformation temperatures in $\mathrm{Cu}-\mathrm{Al}-\mathrm{Be}$ alloys based on their composition [10]. Thus, these alloys can be used in a wide range of temperatures, at ambient temperature or above, but they can be considered also for cryogenic applications [9].

One of the potential applications of $\mathrm{Cu}-\mathrm{Al}$-Be alloys is in seismic devices [11] as they combine several properties: high fatigue resistance, coupled with a low sensitivity for changes in the mechanical behaviour for near-ambient temperatures; they are not very sensitive to frequency changes in the 0.1 to $5 \mathrm{~Hz}$ regime. Moreover their properties suffer slow degradation due to the surrounding environment [12].

In order to allow for the use of these materials in complex shaped applications, it is often required the use of joining techniques [13]. For shape memory alloys, laser welding is considered as the prime choice owning to its characteristics, such as high precision, reproducibility and reduced extension of the thermally affected regions [14]. Laser welding is the most used technique to join shape memory alloys $[15,16]$. This technique has been already successfully employed to preserve the functional properties in similar and dissimilar joints of $\mathrm{Cu}-$ based shape memory alloys, namely CuAlMn [17,18] and CuAlZn [19]. Furthermore, post-weld processing of the laser welded joint can improve the mechanical properties of the material [20]. Aside from obtain defect-free joints, the main concern after welding of such class of materials is to preserve their functional properties, so that they can be used in a given required application. With the more massive use of the aforementioned Cu-based systems, weldability studies on both similar and dissimilar combinations are necessary to understand the potential of these materials in different applications.

Laser welding of Cu-based materials is not easy due to the high reflectivity of these alloys for wavelengths higher than $550 \mathrm{~nm}[21,22]$. Industry-relevant lasers are based on fiber or Nd:YAG, with associated wavelengths of $1064 \mathrm{~nm}$. To make it suitable for industry to join these materials, it is necessary to optimize the process parameters so that these lasers can be used.

In this work the microstructure and mechanical properties of similar laser welded Cu-Al-Be shape memory alloy joint are analysed based on the induced microstructural modifications by the laser/material interaction. This is the first work reporting the effect of laser welding on the mechanical properties of Cu-Al-Be shape memory alloys.

\section{Materials and methods}

\subsection{Laser welding}

Single crystal-like $\mathrm{Cu}-11.5 \mathrm{Al}-0.5 \mathrm{Be}$ (wt\%) shape memory alloy wires produced by modified Bridgman growth technique, $1.25 \mathrm{~mm}$ in diameter, were used in this investigation. Differential scanning calorimetry measurements of the base material has confirmed that it was fully austenitic at room temperature.
Prior to welding, the oxide layer of the base material wire was gently removed using 2500 fine $\mathrm{SiC}$ paper, which lead to a final diameter of $1.24 \mathrm{~mm}$. Acetone and ethanol were used to remove any impurities left in the base material before welding.

Laser welding of the single crystal wires was performed on bead on plate in order to remove joint fit-up as a variable, since this was the first investigation on laser welding of these materials. A Nd:YAG laser (1.064 $\mu \mathrm{m}$ wavelength), from Miyachi Unitek LW50 operating in pulsed mode was used. The laser beam was focused on the surface to a spot diameter of $600 \mu \mathrm{m}$. A schematic representation of the welding setup is depicted in Fig. 1. The welding process was selected in order to obtain full penetration joints, with minimum heat input. After preliminary tests, a $6 \mathrm{~ms}$ pulse profile, which included a $1 \mathrm{~ms}$ up and downslope, and a peak power of $5 \mathrm{~kW}$, ensured complete penetration. To avoid oxidation, $\mathrm{Ar}$ was inserted at the face and root of the welds at a flow rate of $0.6 \mathrm{~m}^{3} \mathrm{~h}^{-1}$

\subsection{Microstructural and mechanical characterization}

After mechanical polishing, the welded joints were prepared for metallographic observations to reveal the microstructure, using an electrolytical polishing a solution of $250 \mathrm{ml}$ of phosphoric acid, $5 \mathrm{~g}$ of urea, $250 \mathrm{ml}$ of ethanol, $50 \mathrm{ml}$ of isopropanol and $500 \mathrm{ml}$ of distilled water, followed by chemical etching with a solution of $10 \mathrm{ml}$ of hydrochloric acid, iron chloride and $100 \mathrm{ml}$ of distilled water. Optical microscopy and scanning electron microscopy (SEM) were performed in the fusion zone and the base material.

The crystallographic texture was determined by X-ray diffraction using a Seifert XRD 3003 PTS 4-circle goniometer. Measurements were performed with a $\mathrm{Cu}-\mathrm{K} \alpha$ radiation operating at $40 \mathrm{kV}$ and $40 \mathrm{~mA}$. The phi $(\Phi)$ angle was varied between 0 and $360^{\circ}$, whereas the psi $(\Psi)$ angle was varied from 0 to $70^{\circ}$. For both angles, the incremental step was of $2^{\circ}$. The $\beta$ austenitic phase has a complex DO3 cubic structure with a cell parameter $\mathrm{a}_{0}=5.825 \AA$ [23]; pole figures were determined for the $\{440\}$ planes. Local crystallographic orientations were determined using Electron Back-Scattered Diffraction (EBSD) maps with a step size of $2 \mu \mathrm{m}$ using a JEOL field electron gun SEM equipped with an Oxford EBSD CCD camera fitted with a FSD detector. EBSD data was treated with the software CHANNEL 5 from Oxford.

Hardness measurements were performed to evaluate the effect of the welding process across the welded joints. A load of $300 \mathrm{~g}$ and a space between indentations of $150 \mu \mathrm{m}$ were used. Three hardness measurement lines were performed at one third, half and two thirds of the sample height.

Mechanical properties of the base material and welded joints were measured during a tensile test at room temperature using an Instron 5548 micro-tensile tester. The gauge length of the samples was of

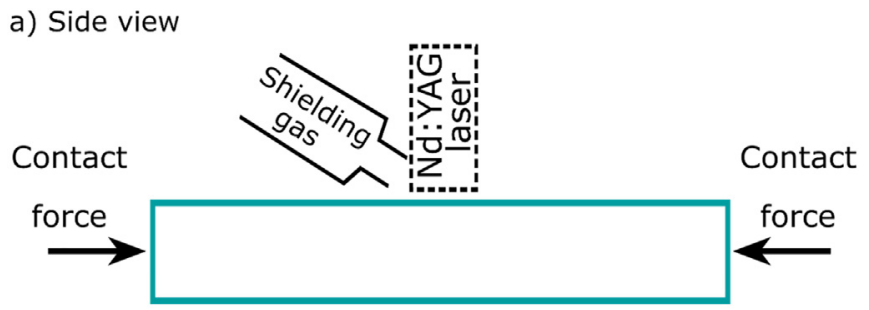

b) Top view

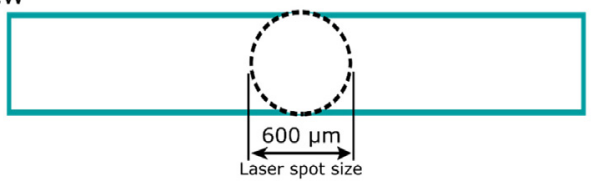

Fig. 1. Schematic representation of the experimental setup for laser welding of CuAlBe shape memory alloy (not to scale): a) side view; b) top view. The laser beam was focused on the surface to a spot diameter of $600 \mu \mathrm{m}$. 
$20 \mathrm{~mm}$; the displacement rate was set at $0.5 \mathrm{~mm} / \mathrm{min}$ and the measurement accuracy is of $\pm 0.5 \mu \mathrm{m}$. Tensile tests were performed on the welded joints. Three samples were tested for reproducibility. Scanning electron microscopy was used to analyse the surface fracture of the joints. Based on the tensile tests performed, the cycling behaviour of the Cu-Al-Be laser welded joints was analysed by performing a total of 10 load/unload cycles. Load/unload cycles up to different maximum strains ranging from 10 to $47.5 \%$ were performed at room temperature, $-40{ }^{\circ} \mathrm{C}$ and $100{ }^{\circ} \mathrm{C}$ to evaluate the effect of temperature on the cycling response.

\section{Results and discussion}

Fig. 2 depicts the microstructure of the laser welded joint. No defects, such as pores or cracks are observed within the fusion. A columnar-like subgrain structure is observed in the fusion zone. This large columnarlike subgrain structure, with lengths of nearly $400 \mu \mathrm{m}$, develops by epitaxial grain growth starting on solid grains of base material on the fusion line [24] and progresses perpendicular to isothermal lines. The grain growth is larger on the areas subjected to higher temperatures and longer residence times [24].

Crystallographic orientations of the base material and the welded joint were deduced from the $\{440\}$ pole figures measurement: both zones exhibit a strong $\langle 100\rangle$ texture in the wire axis. The columnar grains seem to have the same orientation as the initial single crystal. Therefore, the welding process does not contribute to the development of different crystallographic texture within the fusion zone. In order to confirm this result, the welded zone was studied by EBSD (Fig. 3).

EBSD observations confirm that the welded zone has the same orientation as the initial crystal. Misorientation between columnar grains is also very weak: it does not exceed $3^{\circ}$.

In both FCC and BCC metals, the easy growth direction is along the $\langle 100\rangle$ direction $[24,25]$. Two factors contribute for the development of the $\langle 100\rangle$ texture in the fusion zone: this is the easy-growth direction for $\mathrm{Cu}-\mathrm{Al}-\mathrm{Be}$ alloys as these have a complex BCC structure [26]; the base material is oriented in that direction and supports the onset for solidification, thus further favouring such crystallographic orientation $[27,28]$.

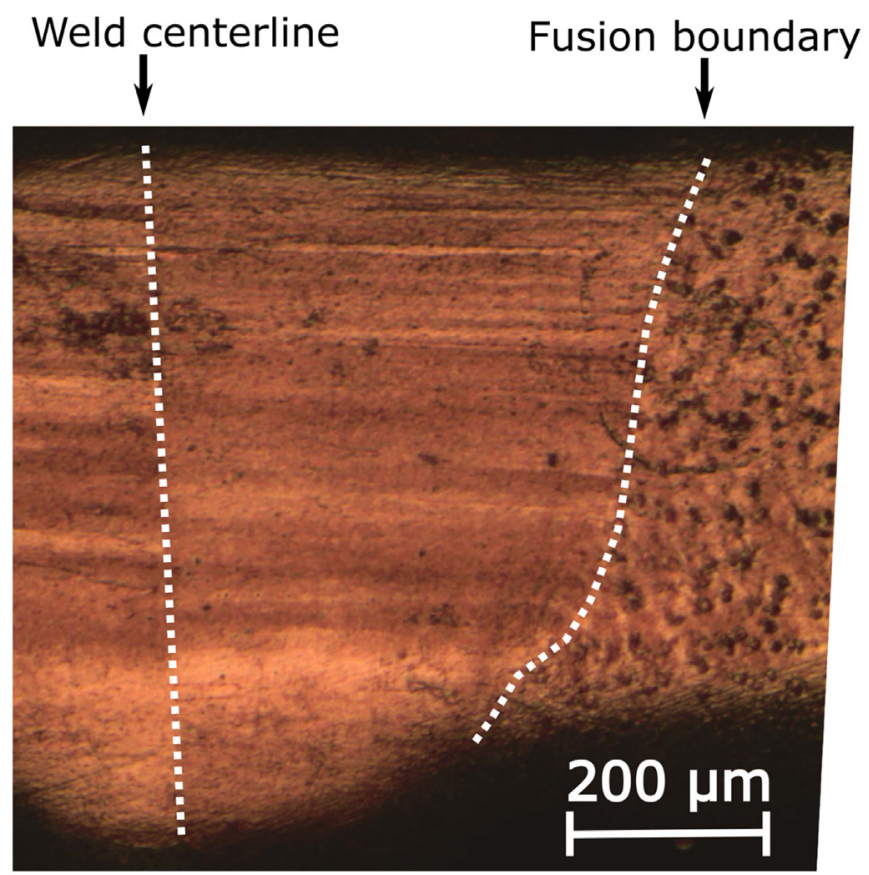

Fig. 2. Microstructure of Cu-Al-Be laser welded joint.
Hardness measurements performed at one third, half and two thirds of the sample height show that the fusion zone has the same hardness as the base material (Fig. 4), with respectively $321.6 \pm 2 \mathrm{HV}$ and $324.5 \pm 3 \mathrm{HV}$. This is in agreement with previous works performed on other laser welding of Cu-Al-based alloys where no significant hardness changes were found between the fusion zone and the base material $[17,20]$.

The tensile behaviour of both base material and welded joints is depicted Fig. 5. It can be observed that the tensile strength of the base material is slightly higher than that of the welded joints (686 $\pm 8 \mathrm{MPa}$ vs $631 \pm 19 \mathrm{MPa}$, respectively). On the other hand, the fracture strain of the joints is higher $(50.8 \pm 0.2 \%$ vs $54.1 \pm 1.2 \%)$. Fracture of the joints occurred in the fusion zone. The higher fracture strain of the welds is probably due to fact that with the refined grain structure of the fusion zone any crack that initiates there will not propagate straightforward along the wire diameter (as it would occur in the single crystal base material), hence allowing the material to deform more. It is interesting to note that the overall tensile properties of the welded joints do not differ significantly from those of the base material, which appears to be a common feature for welded joints of Cu-based shape memory alloys (CuAlMn) [17] but not for NiTi [15,29-31], which is the most studied shape memory alloy.

From Fig. 5 it can also be observed that the stress onset for the martensitic transformation is similar for both base material and welded joints: approximately $400 \mathrm{MPa}$. Although it is known that $\mathrm{Cu}-\mathrm{Al}-\mathrm{Be}$ shape memory alloys have a dependence between grain size and the stress for the onset of the superelastic plateau (the higher the grain size, the lower the stress onset) [32], the volume fraction of the welded region, compared to the remaining base material during tensile testing, is not enough to promote any significant change in respect to this mechanical property.

Fracture analysis of the welded joints was performed using scanning electron microscopy (Fig. 6). Typical ductile-like fracture, characterized by the massive presence of dimples, can be observed. Additionally, it can be detected the presence of minor cracks (marked with white arrows). The presence of those cracks in the fusion zone justifies the higher deformation until fracture of the welds: while in the single crystal base material any crack that form will propagate without any impingement, such as grain boundaries, the same does not occur in the welded joints, as the refined grain structure can delay crack propagation and also enables to accommodate stress.

Due to their lower production costs when compared with NiTi alloys, Cu-based shape memory alloys can be used in energy-absorption devices [5]. For such applications, it is required that the materials in use are able to absorb significant amounts of energy. For shape memory alloys, such dissipation is usually performed in the superelastic regime so that the imposed external deformation can be (ideally) totally restored. For this reason, is important to understand the load/unload cycling behaviour of the welded joints in order to assess the feasibility of their use in such applications.

Based on the tensile behaviour of the welded joints, their cycling behaviour was analysed by a load/unload cycle up to different maximum strains: 10, 20, 37.5 and $47.5 \%$ (Fig. 7). It can be observed that the superelastic plateau extends up to about $40 \%$ strain, as a result of the unique characteristics of the single crystal base material. This means that the transformation strain of the welded joints (the length of the superelastic plateau) is of nearly $35 \%$. Such high transformation strains were also reported in Cu-based alloys [33], but also in the Ni-Ti-Hf system [34]. After the end of the superelastic plateau (corresponding to the applied strain of $47.5 \%$ ) an increasing stress is required to proceed with deformation, where detwinned martensite is first elastically deformed and, subsequently, plastic deformation occurs [35].

From the load/unload behaviour of the joints it is possible to determine the evolution of irrecoverable strain and absorbed energy of the $\mathrm{Cu}-\mathrm{Al}-\mathrm{Be}$ welds as a function of the applied strain, as depicted in Fig. 8. These results were obtained only for the first load/unload mechanical 


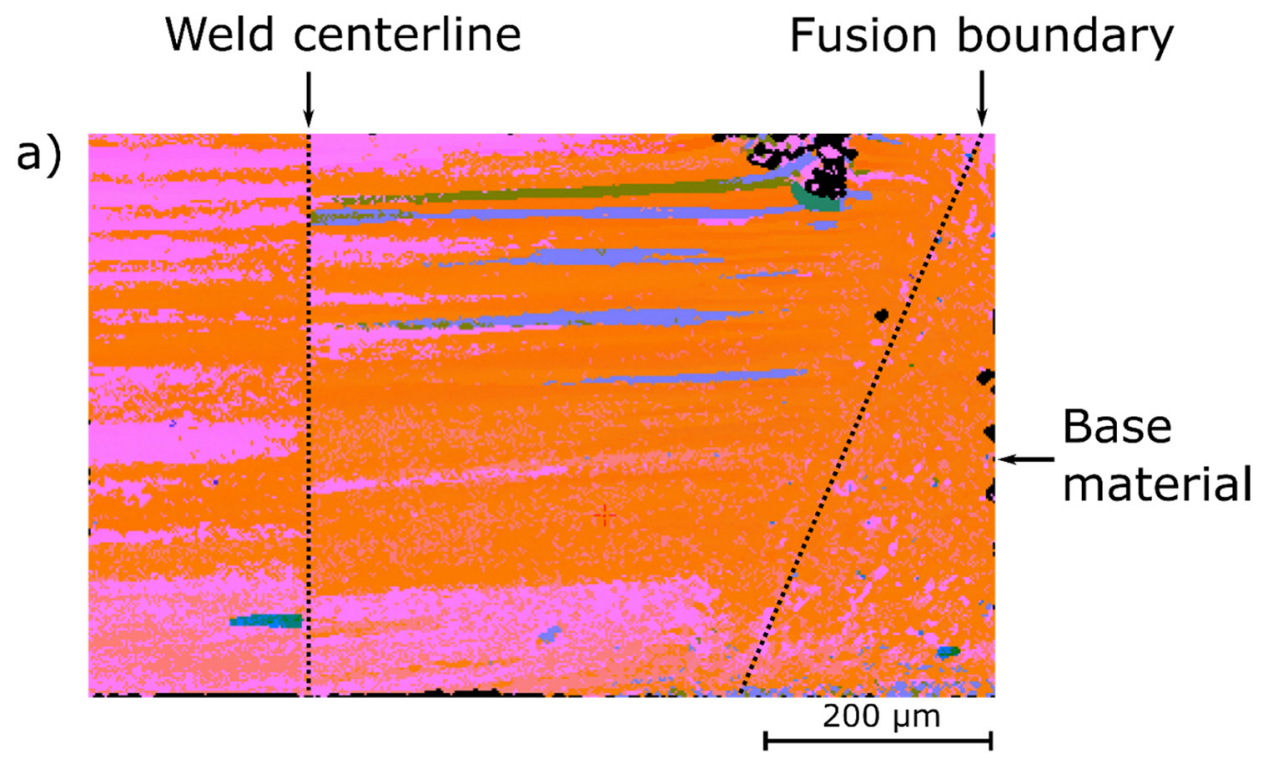

b)

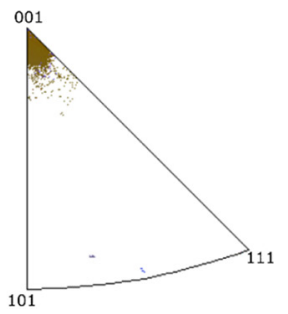

c)

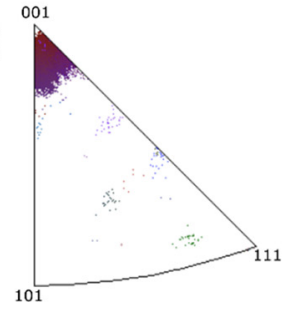

Fig. 3. a) Orientation map determined by EBSD; inverse pole figure in the tensile direction (wire axis) for the initial wire (b) and welded zone (c).

cycle. The very high superelastic recovery of the welds is clearly demonstrated with only $0.6,0.8$ and $1.6 \%$ of irrecoverable strain for maximum applied strains of 10,20 and $37.5 \%$, respectively. The increase of irrecoverable strain with applied strain within the superelastic plateau, may be due to the unfavourable microstructure of the fusion zone of the welds, when compared to the single crystal base material. That is, the slight misorientation of the fusion zone compared to the crystallographic orientation of the base material can account for part of the irrecoverable strain. Ideally, in any deformation performed within the superelastic plateau, the irrecoverable strain, upon unloading, would be null. However, the presence of a refined grain structure in the fusion zone may

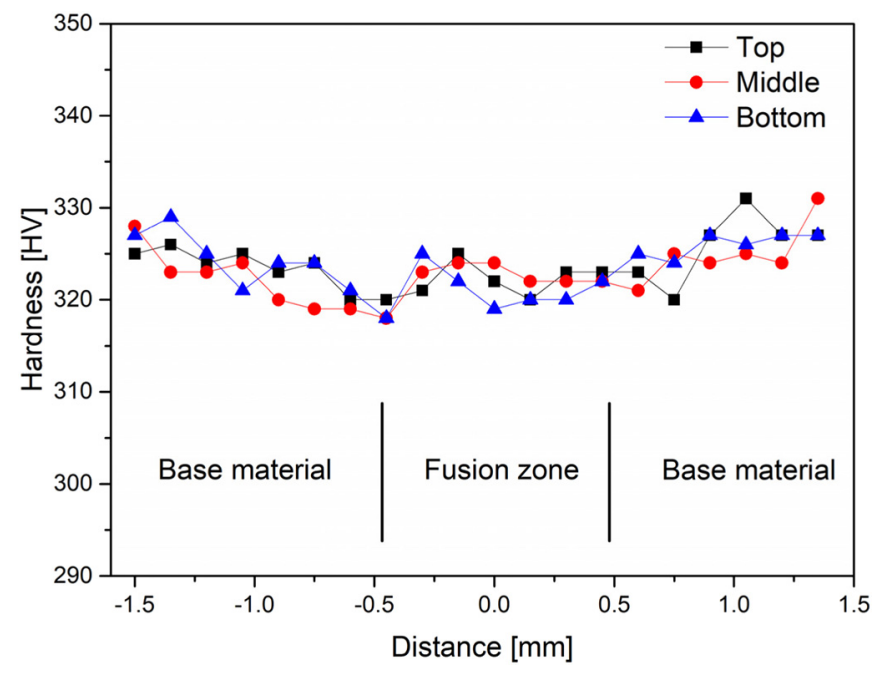

Fig. 4. Hardness measurements results performed at one third (top), half (middle) and two thirds (bottom) of the height of the Cu-Al-Be laser welded joint. inhibit part of the reverse transformation from martensite to austenite during unloading, thus promoting a non-ideal superelastic behaviour, as evidenced in Cu-Al-Be shape memory alloys [36]. However, during the stress induced transformation it is possible that some grains exceed locally the stress for slip to occur [37], which will result in an irrecoverable strain upon unloading [38]. It must be pointed though, that these results are the best, in terms of superelastic recovery during mechanical cycling, for any welded shape memory alloy, when compared to the available literature on the subject $[3,39,40]$.

When the applied strain is increased to $47.5 \%$, the irrecoverable strain increases significantly to $12.3 \%$ as a result of mechanical

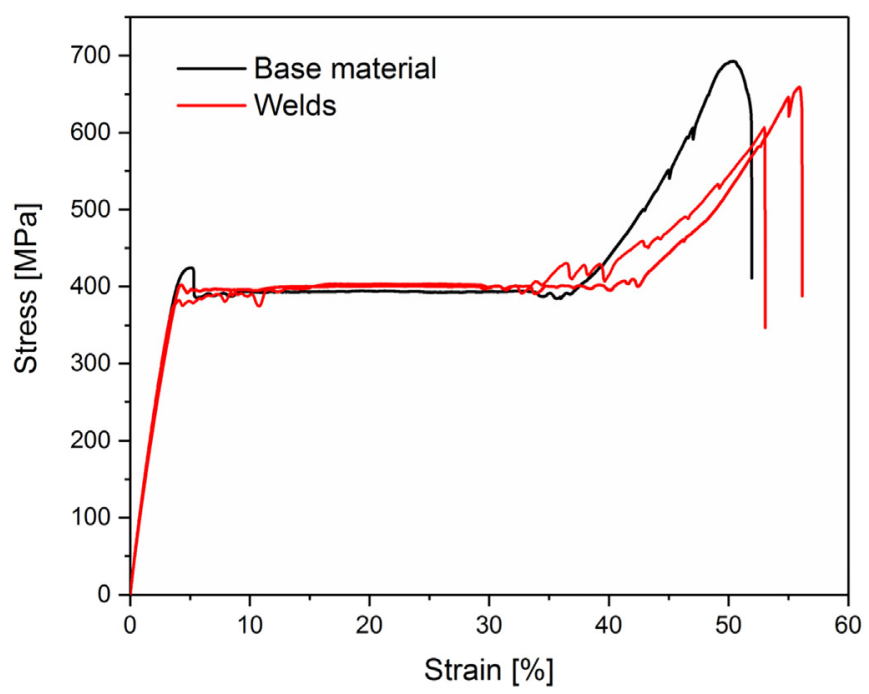

Fig. 5. Tensile behaviour of the $\mathrm{Cu}-\mathrm{Al}-\mathrm{Be}$ base material and laser welded joints. 


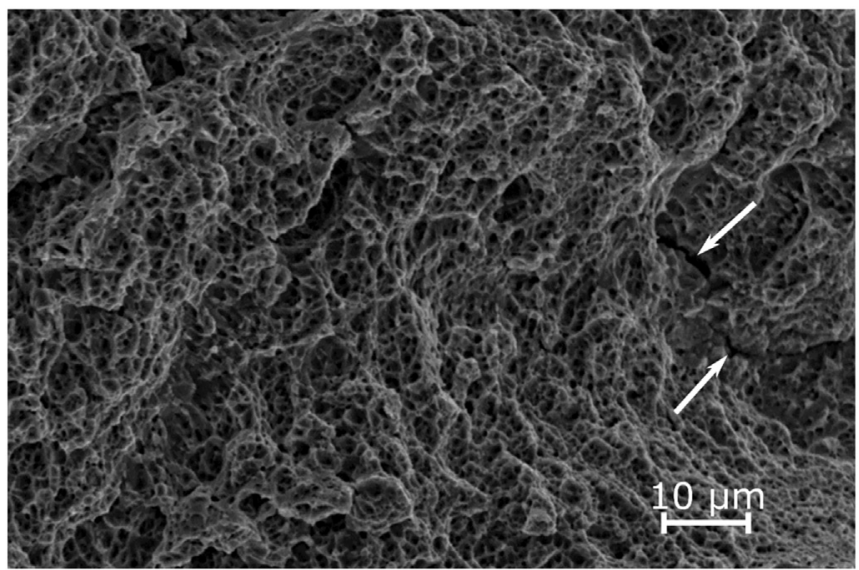

Fig. 6. Fracture surface of the fusion zone the welded joint. The white arrows show other cracks which developed inside the fusion zone.

stabilization of martensite, which is known to occur after the superelastic plateau as results of plastic deformation of martensite [35]. Nonetheless, even for this maximum applied strain, the welded joints were able to recover more than $35 \%$, which is a remarkable result as far as the superelastic behaviour of these joints.

Recently, a new textured Fe28Ni17Co11.5Al2.5Ta0.05B (at. \%) shape memory alloy was found to absorb a significantly high amount of energy during a hysteric load/unload cycle [41], which would be very useful in damping applications, for example. The impressive results presented in [41] are due to the very high stress onset for the beginning of the stress induced transformation and the high mechanical hysteresis between the forward and reverse transformations. In order to compare the absorption behaviour of both the Fe-based shape memory alloy and of the $\mathrm{Cu}-\mathrm{Al}-\mathrm{Be}$ laser welded joint the evolution of the absorbed energy and irrecoverable strain as a function of the applied strain were determined and are presented Fig. 9. The selection of this Fe-based shape memory alloy for comparison with the experimental results obtained for the welded joints is related to the fact that, to the best of the author's knowledge, no other shape memory alloy is known to exhibit such significant energy absorption.

The very high transformation strain of the $\mathrm{Cu}-\mathrm{Al}-\mathrm{Be}$ laser welded joint can exceed the already high absorbed energy of the Fe-based shape memory alloy. However, the high energy absorption capability of the $\mathrm{Cu}-\mathrm{Al}-\mathrm{Be}$ weld comes at an expense of a slight irrecoverable strain, when compared to the Fe-based shape memory alloy.

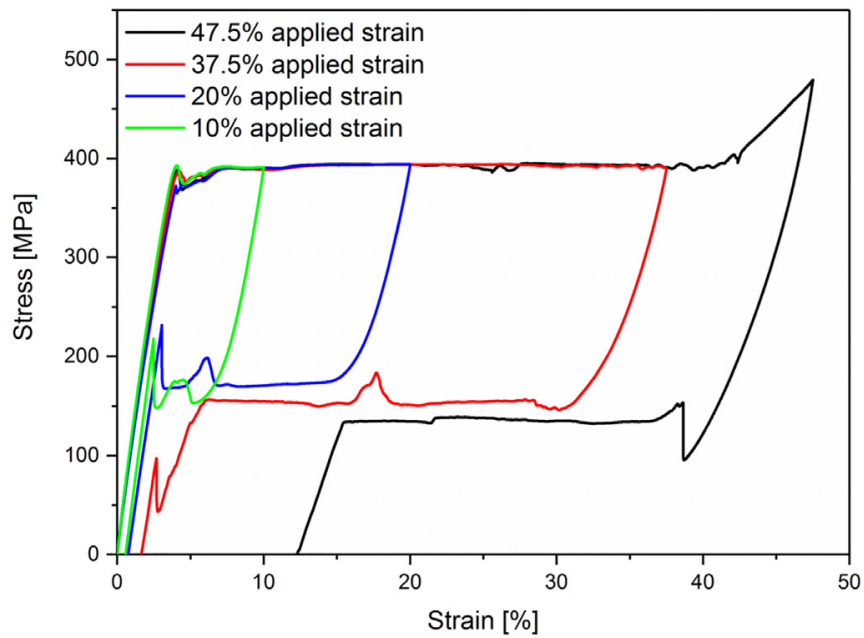

Fig. 7. Load/unload cycling behaviour of the welded joints.

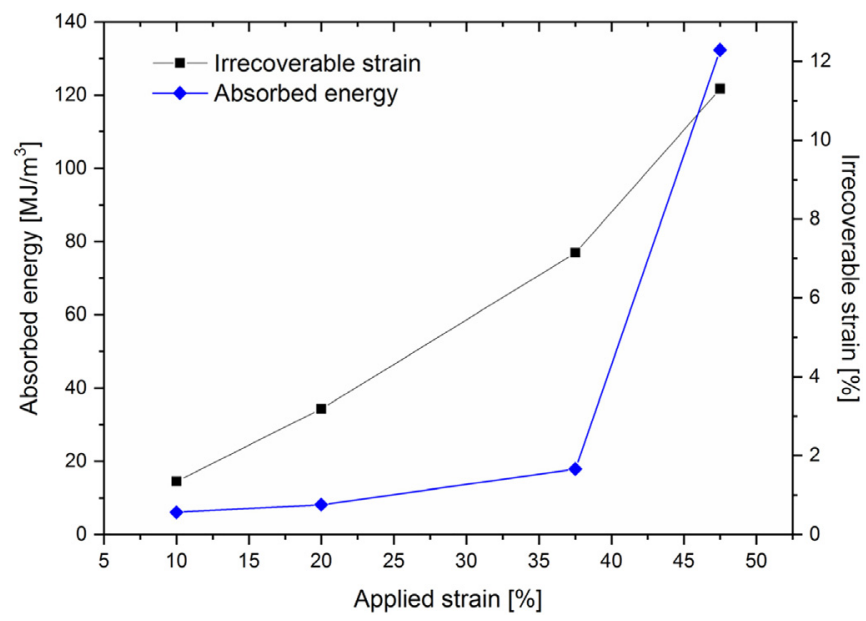

Fig. 8. Irrecoverable strain and absorbed energy as a function of applied strain during one load/unload cycle for the welded joint.

Nonetheless, these cycling results show the potential for such laser welded joints to be used in energy-absorption applications, such as seismic devices, where large amount of energy need to be absorbed.

Cu-based shape memory alloys have potential applications as seismic devices for energy absorption [42,43]. However, for these materials to be used in such applications it is necessary that the superelastic behaviour is stable for a wide range of temperatures [44], below $-10^{\circ} \mathrm{C}$ and up to $50^{\circ} \mathrm{C}$, ideally.

The laser welded $\mathrm{Cu}-\mathrm{Al}-\mathrm{Be}$ joints were also subjected to a total of 10 load/unload cycles up to $37.5 \%$ strain at $-40{ }^{\circ} \mathrm{C}, 23{ }^{\circ} \mathrm{C}$ (room temperature) and $100^{\circ} \mathrm{C}$. These results are depicted in Fig. 10 , showing only the 1 st, 5 th and 10 th cycles for clarity purposes.

One of the most remarkable features observed from these cycling tests at different temperatures is the double step plateau which occurred at $-40{ }^{\circ} \mathrm{C}$ (Fig. 10 a). However, this two-step plateau is not observed in the cycling tests performed at both room temperature and $100{ }^{\circ} \mathrm{C}$. Cu-Al-Be shape memory alloys have their stress induced martensitic transformation occurring in the following sequence: $\beta$ austenite $\rightarrow 18 \mathrm{R}$ martensite $\rightarrow$ 6R martensite. However, the presence of the two-step plateau is evidenced or not depending on the test temperature. In [45], the authors performed load/unload testing on $\mathrm{Cu}-\mathrm{Al}$ Be shape memory alloys at different temperatures and observed that

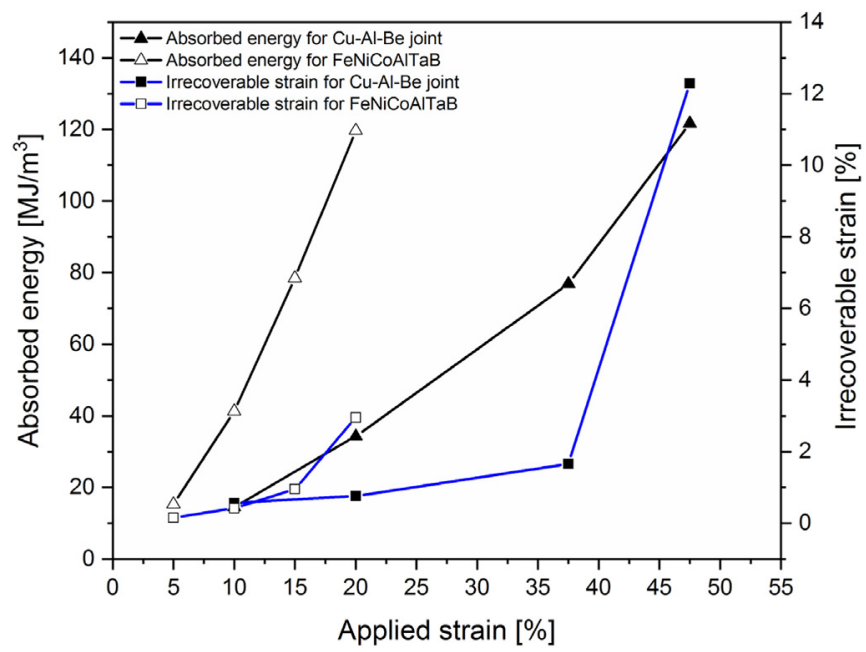

Fig. 9. Evolution of the absorbed energy and irrecoverable strain as a function of the applied strain during superelasticity cycling: comparison between the $\mathrm{Cu}-\mathrm{Al}-\mathrm{Be}$ laser welded joint and the Fe28Ni17Co11.5Al2.5Ta0.05B (at. \%), noted as FeNiCoAITaB, shape memory alloy [41]. 

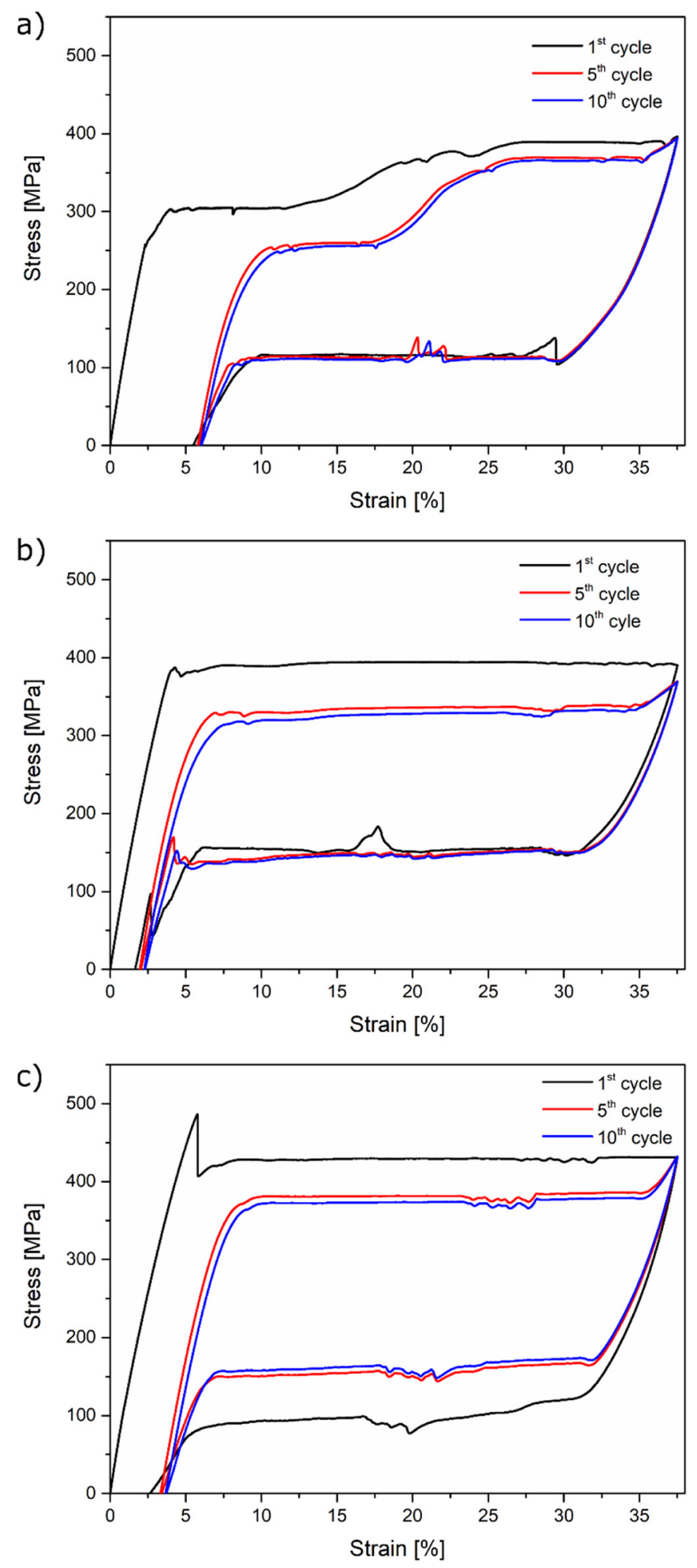

Fig. 10. Cycling tests up to $37.5 \%$ strain at different temperatures: a) $-40{ }^{\circ} \mathrm{C}$; b) room temperature $\left.\left(23^{\circ} \mathrm{C}\right) ; \mathrm{c}\right) 100{ }^{\circ} \mathrm{C}$.

at lower testing temperatures the two step plateaus were clearly distinguished. With temperature increase, the first martensitic transformation $(\beta \rightarrow 18 R)$ starts at significantly higher stress levels, whereas the second martensitic transformation $(18 R \rightarrow 6 R)$ starts at a lower stress level. Further increase of the testing temperature would cause for both plateaus to occur at the same stress level. Similar observations were performed in fundamental studies on the mechanical behaviour of CuAlBe shape memory alloys [45].
Of special relevance on the martensitic transformations of $\mathrm{Cu}-\mathrm{Al}-\mathrm{Be}$ shape memory alloys is the dependence of both transformations, $\beta$ $\rightarrow 18 \mathrm{R}$ and $18 \mathrm{R} \rightarrow 6 \mathrm{R}$, with temperature: the $\beta \rightarrow 18 \mathrm{R}$ has a positive Clausius-Clapeyron relation of $1.86 \mathrm{MPa} / \mathrm{K}$, while for the $18 \mathrm{R} \rightarrow 6 \mathrm{R}$ transformation the relation is of $-0.28 \mathrm{MPa} / \mathrm{K}$. This means that the temperature effect on the stress onset for the start of the martensitic transformation on Cu-Al-Be shape memory alloys in extremely important for the $\beta \rightarrow 18 R$ transformation, whereas in the $18 R \rightarrow 6 R$ transformation the temperature effect is almost negligible and tends to decrease the stress onset for the transformation to occur.

In the cycling tests performed at $23^{\circ} \mathrm{C}$ and $100{ }^{\circ} \mathrm{C}$ only a unique plateau is visible meaning that overlapping between the two stress induced transformation has occurred at these temperatures.

The irrecoverable strain upon unloading in the first load/unload cycle varies with no apparent influence of the temperature. This is related to the fact that during the first superelastic cycles at which shape memory alloys are subject material accommodation occurs. In this case only one load/unload cycle is required for the following cycling tests to present a stabilized behaviour, that is, the irrecoverable strain and mechanical hysteresis between consecutive load/unload cycles is minimal. In fact, the evolution of the accumulated irrecoverable strain and the stress onset for the forward martensitic transformation do not vary significantly after the first load/unload cycle.

Cycling behaviour analysis is laser welded NiTi shape memory alloys showed an increase in the accumulated irrecoverable strain due to introduction of dislocations that stabilize martensite, preventing the transformation to austenite upon unloading, thus not participating further in the superelastic behaviour [40,46]. Additionally, the introduction of internal residual stresses during superelastic cycling of shape memory alloys justifies the decreasing external stress required for the martensitic transformation to occur [47], as depicted in Fig. 11 b).

The temperature effect on the necessary stress for the martensitic transformation to occur is clearly observed in Fig. $11 \mathrm{~b}$ ): with increasing temperature, higher stress is required for the transformation to occur, which correlated well with a positive Clausius-Clapeyron relation when the $\beta \rightarrow 18 \mathrm{R}$ transformation occurs.

The evolution of the energy absorbed as function of the number of load/unload cycles at the different testing temperatures is depicted in Fig. $11 \mathrm{c}$ ). It can be observed that the first cycle has the higher absorbed energy for all testing temperatures. This is related to the fact that in the following cycles the a given irrecoverable strain has already occurs which reduces the total superelastic strain of the welded joint. At 100 ${ }^{\circ} \mathrm{C}$, the absorbed energy is slightly higher than at the other two testing temperatures. This is related to the Clausius-Clapeyron effects which rises the stress onset for the stress induced transformation, which translates into a higher capacity for energy absorption. At $-40{ }^{\circ} \mathrm{C}$ and room temperature the absorbed energy does not vary significantly, despite the two step plateau observed at $-40^{\circ} \mathrm{C}$.

\section{Conclusions}

Defect-free joints were obtained when laser welding of $\mathrm{Cu}-\mathrm{Al}-\mathrm{Be}$ shape memory alloys and this study shows the potential to use such high energy density welding process for joining these alloys. The following major conclusions can be drawn:

- The crystallographic texture of the fusion zone was not modified by the welding processes, following the same orientation as the base material;

- No significant hardness changes were determined between the fusion zone and base material;

- The tensile strength of the laser welded joints is slightly lower than the base material (686 vs $631 \mathrm{MPa}$ ), whereas the tensile strain was higher for the welds ( 50.8 vs $54.1 \%$ ). This was attributed to the microstructure in the fusion zone, which sustain a higher amount of deformation owing to the presence of obstacles that oppose to crack propagation.

- Superelastic behaviour of the welded joints was preserved with 


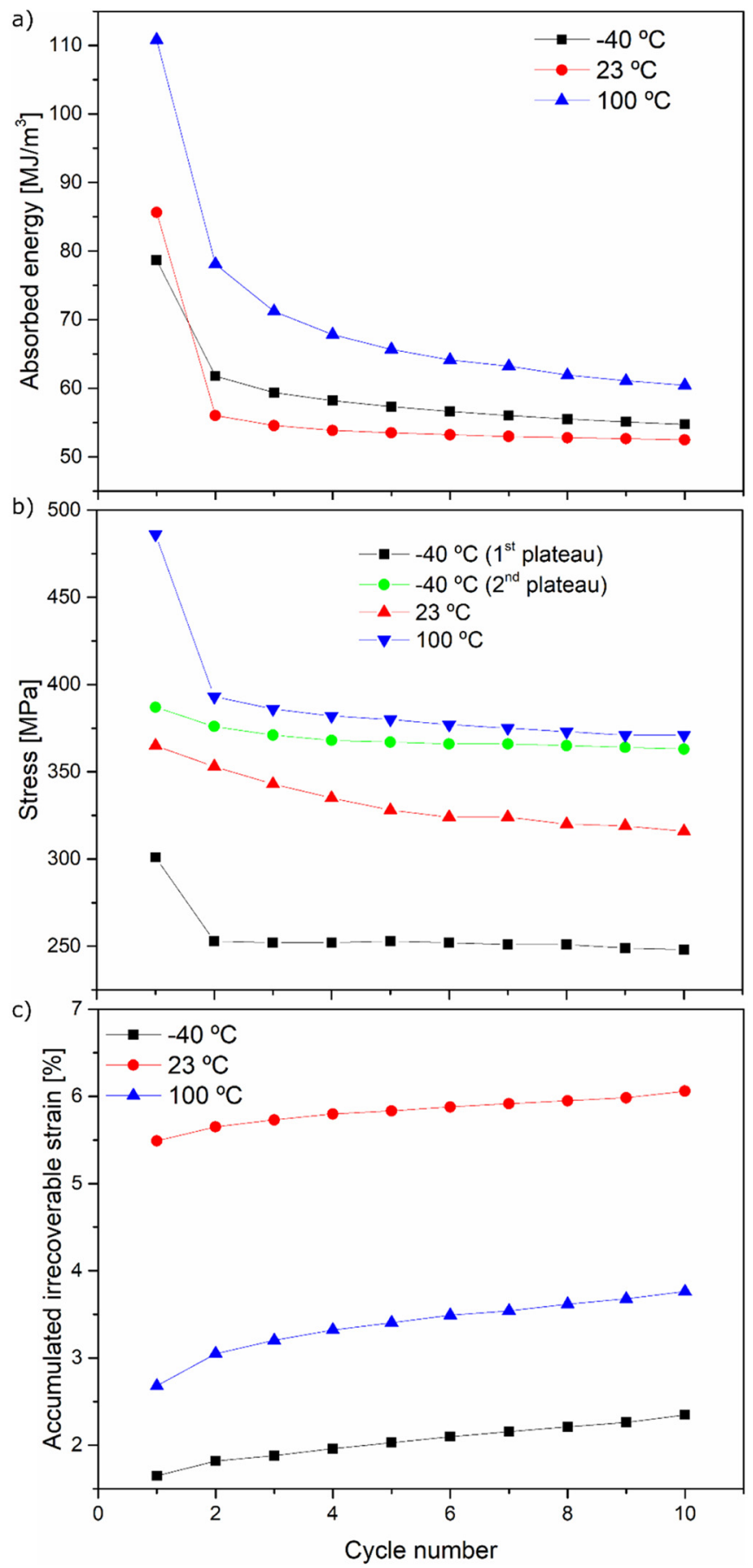

Fig. 11. a) Evolution of the accumulated irrecoverable strain with the number of load/ unload cycling tests; b) Evolution of the stress onset for the forward martensitic transformation with the number of load/unload cycling tests; c) Evolution of the absorbed energy with the number of load/unload cycling tests.

associated high energy absorption capabilities and transformation strain. Moreover, in the temperature range of -40 to $100{ }^{\circ} \mathrm{C}$, the laser welded joint exhibits superelastic behaviour. These features make these joints potential candidates for applications requiring large damping capabilities, such as in seismic systems.

\section{Data availability}

The raw/processed data required to reproduce these findings cannot be shared at this time as the data also forms part of an ongoing study.

\section{Acknowledgements}

The authors gratefully acknowledge Professor Toshihiro Omori from Tohoku University for providing the raw data of the cycling tests performed on the Fe28Ni17Co11.5Al2.5Ta0.05B at. \% shape memory alloy. JPO and FMBF acknowledge funding by National Funds through the Portuguese Foundation for Science and Technology (FCT-MCTES), Reference UID/CTM/50025/2013 and FEDER funds through the COMPETE 2020 Programme under the project number POCI-01-0145-FEDER007688. RMM acknowledges FCT-MCTES for its financial support via the project PEst-OE/EME/UI0667/2014 (UNIDEMI). JPO acknowledges FCT/MCTES for funding PhD grant SFRH/BD/85047/2012 and stay at Waterloo University (Canada) through MIDAS Project No 612585 "MIDAS - Micro and Nanoscale Design of Thermally Actuating Systems" Marie Curie Actions, FP7-PEOPLE-2013-IRSES. ZZ and JPO acknowledge National Natural Science Foundation of China (51775091).

\section{References}

[1] J.M. Jani, M. Leary, A. Subic, M.a. Gibson, J. Mohd Jani, M. Leary, A. Subic, M.a. Gibson, A review of shape memory alloy research, applications and opportunities, Mater. Des. 56 (2014) 1078-1113, https://doi.org/10.1016/j.matdes.2013.11.084.

[2] E. Patoor, D.C. Lagoudas, P.B. Entchev, L.C. Brinson, X. Gao, Shape memory alloys, part I: general properties and modeling of single crystals, Mech. Mater. 38 (2006) 391-429, https://doi.org/10.1016/j.mechmat.2005.05.027.

[3] J.P. Oliveira, R.M. Miranda, F.M. Braz Fernandes, Welding and joining of NiTi shape memory alloys: a review, Prog. Mater. Sci. 88 (2017) 412-466, https://doi.org/10. 1016/j.pmatsci.2017.04.008.

[4] Y. Sutou, T. Omori, J.J. Wang, R. Kainuma, K. Ishida, Characteristics of Cu-Al-Mnbased shape memory alloys and their applications, Mater. Sci. Eng. A 378 (2004) 278-282, https://doi.org/10.1016/j.msea.2003.12.048.

[5] Y. Sutou, T. Omori, K. Yamauchi, N. Ono, R. Kainuma, K. Ishida, Effect of grain size and texture on pseudoelasticity in Cu-Al-Mn-based shape memory wire, Acta Mater. 53 (2005) 4121-4133, https://doi.org/10.1016/j.actamat.2005.05.013.

[6] Y. Sutou, N. Koeda, T. Omori, R. Kainuma, K. Ishida, Effects of ageing on bainitic and thermally induced martensitic transformations in ductile Cu-Al-Mn-based shape memory alloys, Acta Mater. 57 (2009) 5748-5758, https://doi.org/10.1016/j. actamat.2009.08.003.

[7] J. San Juan, M.L. Nó, C.A. Schuh, Superelastic cycling of Cu-Al-Ni shape memory alloy micropillars, Acta Mater. 60 (2012) 4093-4106, https://doi.org/10.1016/j.actamat. 2012.04.021.

[8] I. Lopez-Ferreño, T. Breczewski, I. Ruiz-Larrea, A. Lopez-Echarri, M.L. Nó, J. San Juan, Thermal treatments and transformation behavior of Cu-Al-Be shape memory alloys, J. Alloys Compd. 577 (2013) 463-467, https://doi.org/10.1016/j.jallcom.2012.02. 006.

[9] V.H.C. de Albuquerque, T.A. de A. Melo, D.F. de Oliveira, R.M. Gomes, J.M.R.S. Tavares, Evaluation of grain refiners influence on the mechanical properties in a CuAlBe shape memory alloy by ultrasonic and mechanical tensile testing, Mater. Des. 31 (2010) 3275-3281, https://doi.org/10.1016/j.matdes.2010.02.010.

[10] S. Montecinos, M.O. Moroni, A. Sepúlveda, Superelastic behavior and damping capacity of CuAlBe alloys, Mater. Sci. Eng. A 419 (2006) 91-97, https://doi.org/10. 1016/j.msea.2005.11.057.

[11] A. Sepulveda, R. Muñoz, F.C. Lovey, C. Auguet, A. Isalgue, V. Torra, Metastable effects on martensitic transformation in SMA, J. Therm. Anal. Calorim. 89 (2007) 101-107, https://doi.org/10.1007/s10973-005-7480-3.

[12] R. Araya, M. Marivil, C. Mir, O. Moroni, A. Sepúlveda, Temperature and grain size effects on the behavior of CuAlBe SMA wires under cyclic loading, Mater. Sci. Eng. A 496 (2008) 209-213, https://doi.org/10.1016/j.msea.2008.05.030.

[13] Z. Zeng, M. Yang, J.P. Oliveira, D. Song, B. Peng, Laser welding of NiTi shape memory alloy wires and tubes for multi-functional design applications, Smart Mater. Struct. 25 (2016), 85001. https://doi.org/10.1088/0964-1726/25/8/085001.

[14] W.M. Steen, J. Mazumder, Laser Material Processing, Springer London, London, 2010https://doi.org/10.1007/978-1-84996-062-5.

[15] Y.G.G. Song, W.S.S. Li, L. Li, Y.F.F. Zheng, The influence of laser welding parameters on the microstructure and mechanical property of the as-jointed NiTi alloy wires, Mater. Lett. 62 (2008) 2325-2328, https://doi.org/10.1016/j.matlet.2007.11.082.

[16] M.H. Sadati, Y. Javadi, Investigation of mechanical properties in welding of shape memory alloys, Procedia Eng. 149 (2016) 438-447, https://doi.org/10.1016/j. proeng.2016.06.690.

[17] J.P. Oliveira, B. Panton, Z. Zeng T. Omori, Y. Zhou, R.M. Miranda, F.M. Braz Fernandes, Laser welded superelastic $\mathrm{Cu}-\mathrm{Al}-\mathrm{Mn}$ shape memory alloy wires, Mater. Des. 90 (2016) 122-128, https://doi.org/10.1016/j.matdes.2015.10.125.

[18] J.P. Oliveira, Z. Zeng, C. Andrei, F.M. Braz Fernandes, R.M. Miranda, A.J. Ramirez, T. Omori, N. Zhou, Dissimilar laser welding of superelastic NiTi and CuAlMn shape memory alloys, Mater. Des. 128 (2017) 166-175, https://doi.org/10.1016/j.matdes. 2017.05.011.

[19] C.A. Biffi, B. Previtali, A. Tuissi, Microstructure and calorimetric behavior of laser welded open cell foams in CuZnAl shape memory alloy, Funct. Mater. Lett. 9 (2016), 1642007. https://doi.org/10.1142/S1793604716420078.

[20] J.P. Oliveira, Z. Zeng, T. Omori, N. Zhou, R.M. Miranda, F.M.B. Fernandes, Improvement of damping properties in laser processed superelastic $\mathrm{Cu}-\mathrm{Al}-\mathrm{Mn}$ shape 
memory alloys, Mater. Des. 98 (2016) 280-284, https://doi.org/10.1016/j.matdes. 2016.03.032.

[21] C. Yao, B. Xu, X. Zhang, J. Huang, J. Fu, Y. Wu, Interface microstructure and mechanical properties of laser welding copper-steel dissimilar joint, Opt. Lasers Eng. 47 (2009) 807-814, https://doi.org/10.1016/j.optlaseng.2009.02.004.

[22] S.V. Kuryntsev, A.E. Morushkin, A.K. Gilmutdinov, Fiber laser welding of austenitic steel and commercially pure copper butt joint, Opt. Lasers Eng. 90 (2017) 101-109, https://doi.org/10.1016/j.optlaseng.2016.10.008.

[23] S. Montecinos, A. Cuniberti, Thermomechanical behavior of a CuAlBe shape memory alloy, J. Alloys Compd. 457 (2008) 332-336, https://doi.org/10.1016/j.jallcom.2007. 03.077.

[24] S. Kou, Welding Metallurgy, 2nd ed. John Wiley \& Sons, Inc., Hoboken, 2002https:// doi.org/10.1002/0471434027.

[25] S.A. David, S.S. Babu, J.M. Vitek, Welding: solidification and microstructure, JOM 55 (2003) 14-20, https://doi.org/10.1007/s11837-003-0134-7.

[26] S. Montecinos, A. Cuniberti, Martensitic transformation and grain size in a $\mathrm{Cu}-\mathrm{Al}-\mathrm{Be}$ alloy, Procedia Mater. Sci. 1 (2012) 149-155, https://doi.org/10.1016/j.mspro.2012. 06.020.

[27] S.A. David, J.M. Vitek, Correlation between solidification parameters and weld microstructures, Int. Mater. Rev. 34 (1989) 213-245, https://doi.org/10.1179/imr. 1989.34.1.213.

[28] J.W. Park, S.S. Babu, J.M. Vitek, E.A. Kenik, S.A. David, Stray grain formation in single crystal Ni-base superalloy welds, J. Appl. Phys. 94 (2003) 4203-4209, https://doi. org/10.1063/1.1602950.

[29] A. Tuissi, S. Besseghini, T. Ranucci, F. Squatrito, M. Pozzi, Effect of Nd-YAG laser welding on the functional properties of the Ni-49.6at.\%Ti, Mater. Sci. Eng. A 273-275 (1999) 813-817, https://doi.org/10.1016/S0921-5093(99)00422-0.

[30] H. Gugel, A. Schuermann, W. Theisen, Laser welding of NiTi wires, Mater. Sci. Eng. A 481-482 (2008) 668-671, https://doi.org/10.1016/j.msea.2006.11.179.

[31] C.W. Chan, H.C. Man, T.M. Yue, Effects of process parameters upon the shape memory and pseudo-elastic behaviors of laser-welded NiTi thin foil, Metall. Mater. Trans. A Phys. Metall. Mater. Sci. 42 (2011) 2264-2270, https://doi.org/10.1007/s11661011-0623-1.

[32] S. Montecinos, A. Cuniberti, A. Sepúlveda, Grain size and pseudoelastic behaviour of a Cu-Al-Be alloy, Mater. Charact. 59 (2008) 117-123, https://doi.org/10.1016/j. matchar.2006.11.009.

[33] G. Mussot-Hoinard, E. Patoor, A. Eberhardt, Influence of Resistance Welding on the Properties of a CuAlBe Single Crystal Shape Memory Alloy, in: ICOMAT, John Wiley \& Sons, Inc., Hoboken, NJ, USA, 2013 555-559, https://doi.org/10.1002/ 9781118803592.ch81.

[34] Y. Wu, L. Patriarca, H. Sehitoglu, Y. Chumlyakov, Ultrahigh tensile transformation strains in new Ni 50.5 Ti 36.2 Hf 13.3 shape memory alloy, Scr. Mater. 118 (2016) 51-54, https://doi.org/10.1016/j.scriptamat.2016.03.009.

[35] K. Otsuka, X. Ren, Physical metallurgy of Ti-Ni-based shape memory alloys, Prog. Mater. Sci. 50 (2005) 511-678, https://doi.org/10.1016/j.pmatsci.2004.10.001.
[36] B. Kaouache, S. Berveiller, K. Inal, A. Eberhardt, E. Patoor, Stress analysis of martensitic transformation in Cu-Al-Be polycrystalline and single-crystalline shape memory alloy, Mater. Sci. Eng. A 378 (2004) 232-237, https://doi.org/10.1016/j.msea.2003. 10.348.

[37] P. Sedmak, J. Pilch, L. Heller, J. Kopecek, J. Wright, P. Sedlak, M. Frost, P. Sittner, P. Sedmák, J. Pilch, L. Heller, J. Kopeček, J. Wright, P. Sedlák, M. Frost, P. Šittner, Grain-resolved analysis of localized deformation in nickel-titanium wire under tensile load, Science 353 (2016) 559-562 (80-.) https://doi.org/10.1126/science. aad6700.

[38] J.P. Oliveira, F.M. Braz Fernandes, R.M. Miranda, N. Schell, J.L. Ocaña, Effect of laser welding parameters on the austenite and martensite phase fractions of NiTi, Mater. Charact. 119 (2016) 148-151, https://doi.org/10.1016/j.matchar.2016.08. 001.

[39] P. Krooß, J. Günther, L. Halbauer, M. Vollmer, A. Buchwalder, R. Zenker, H. Biermann, T. Niendorf, Electron beam welding of Fe-Mn-Al-Ni shape memory alloy: microstructure evolution and shape memory response, Funct. Mater. Lett. 10 (2017), 1750043. https://doi.org/10.1142/S1793604717500436.

[40] J.P. Oliveira, R.M. Miranda, N. Schell, F.M. Braz Fernandes, High strain and long duration cycling behavior of laser welded NiTi sheets, Int. J. Fatigue 83 (2016) 195-200, https://doi.org/10.1016/j.ijfatigue.2015.10.013.

[41] Y. Tanaka, Y. Himuro, R. Kainuma, Y. Sutou, T. Omori, K. Ishida, Ferrous polycrystalline shape-memory alloy showing huge superelasticity, Science 327 (2010) 1488-1490 (80-.) https://doi.org/10.1126/science.1183169.

[42] Y. Araki, N. Maekawa, T. Omori, Y. Sutou, R. Kainuma, K. Ishida, Rate-dependent response of superelastic $\mathrm{Cu}-\mathrm{Al}-\mathrm{Mn}$ alloy rods to tensile cyclic loads, Smart Mater. Struct. 21 (2012), 32002. https://doi.org/10.1088/0964-1726/21/3/032002.

[43] Y. Araki, N. Maekawa, K.C. Shrestha, M. Yamakawa, Y. Koetaka, T. Omori, R. Kainuma, Feasibility of tension braces using Cu-Al-Mn superelastic alloy bars, Struct. Control. Health Monit. 21 (2014) 1304-1315, https://doi.org/10.1002/stc.1644.

[44] Y.Zhang, J.A. Camilleri, S. Zhu, Mechanical properties of superelastic Cu-Al-Be wires at cold temperatures for the seismic protection of bridges, Smart Mater. Struct. 17 (2008), 25008. https://doi.org/10.1088/0964-1726/17/2/025008.

[45] M. Sade, A. Yawny, F.C. Lovey, V. Torra, Pseudoelasticity of Cu-Al-Be single crystals: unexpected mechanical behavior, Mater. Sci. Eng. A 528 (2011) 7871-7877, https:// doi.org/10.1016/j.msea.2011.07.021.

[46] J.P. Oliveira, F.M.B. Fernandes, N. Schell, R.M. Miranda, Martensite stabilization during superelastic cycling of laser welded NiTi plates, Mater. Lett. 171 (2016) 273-276, https://doi.org/10.1016/j.matlet.2016.02.107.

[47] S. Miyazaki, T. Imai, Y. Igo, K. Otsuka, Effect of cyclic deformation on the psedoelasticity characteristics of Ti-Ni alloys, Metall. Trans. A 17 (A) (1986) 115-120http://www.scopus.com/inward/record.url?eid=2-s2.00022544716\&partnerID $=$ tZOtx3y1. 